\title{
Multiple Glioma-A Case Reports
}

\section{Amit Kumar G*}

Consultant Neurosurgeon, National Neurosciences BK Roy Research Centre, India

Submission: April 13, 2017; Published: June 30, 2017

*Corresponding author: Amit Kumar G, National Neurosciences Centre, Calcutta, Peerless Hospital and BK Roy Research Centre, Kolkata, India, Email: amitghosh74@yahoo.co.in

\begin{abstract}
Multiple gliomas are uncommon tumors. The incidence of multiple gliomas ranges from $0.5 \%$ to $20 \%$ of all gliomas diagnosed. Multiple gliomas can be divided into two ways. One is by location of the lesions (multifocal and multicentric). The second way is by the time of the lesions occur (synchronous and metachronous). The prognosis of multiple gliomas remains unfavourable. The treatment of multiple gliomas includes surgery, radiotherapy and chemotherapy. Distinction between multicentric and multifocal gliomas is difficult. This is a case report of multicentric variety of multiple gliomas which was treated with surgery and adjuvant therapy. Literature was reviewed and analysed.
\end{abstract}

Keywords: Multiple glioma; Multifocal glioma; Multicentric glioma

Introduction

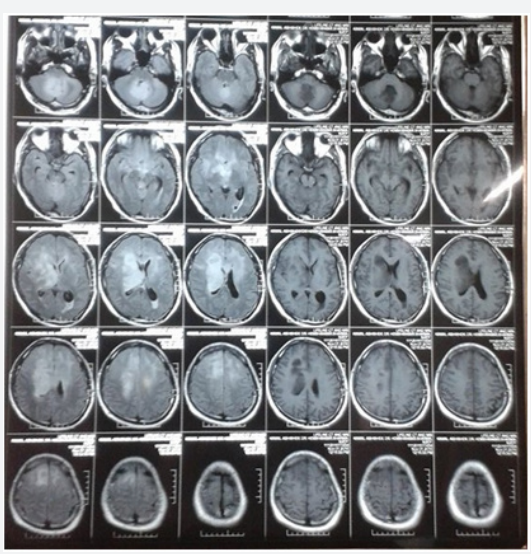

Figure1: MRI brain showed hypointense lesion in T1.

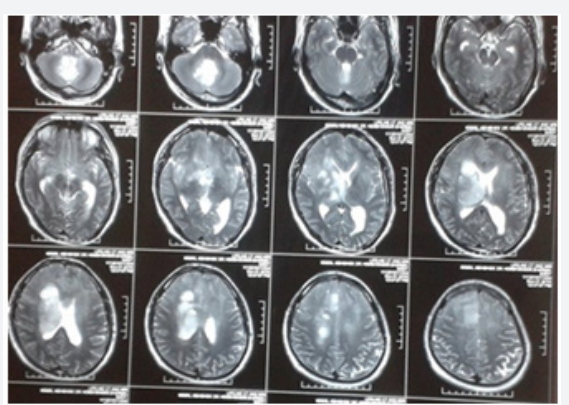

Figure 2: MRI brain showed hypointense lesion in T1

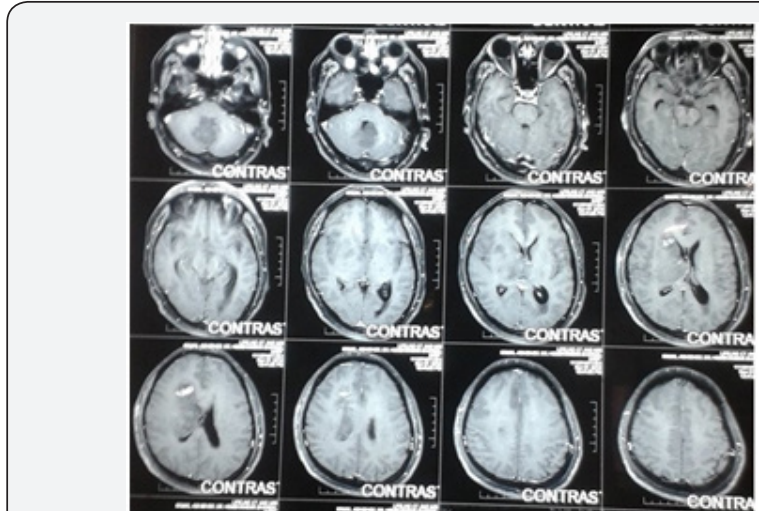

Figure 3: Cerebellum and left frontal region with small area contrast enhancement.

A 30 years old young man presented with headache and repeated vomiting with unsteady walking for 2 weeks. On examination, he was looking very sick because of headache and vomiting. He was conscious, oriented, verbalising well. There was left sided hemiparesis. MRI brain showed hypointense lesion in T1 (Figure1), hyperintense in Flair (Figure1) and T2 (Figure 2), in right frontal, basal ganglia, thalamus, sub thalamus, cerebellum and left frontal region with small area contrast enhancement (Figure 3) at right frontal region near caudate nucleus. Right frontal craniotomy and biopsy from right frontal lesion was done. Histopathology showed diffuse glioma (WHO grade II) with IDH1 (isocitrate dehydrogenase) mutation 
positive. Patient was referred to radiation oncologist for further management.

\section{Discussion}

Multiple gliomas are uncommon tumors. The incidence of multiple gliomas ranges from $0.5 \%$ to $20 \%$ of all gliomas diagnosed. Multiple gliomas can be divided into two ways [1]. One is by location of the lesions (multifocal and multicentric). The second way is by the time of the lesions occur (synchronous and metachronous). Multicentric gliomas are well-separated lesions, located in different lobes or hemispheres, which cannot be ascribed to dissemination through commissural pathways, cerebrospinal- fluid (CSF), blood or local extension. Multicentric glioma consists of tumors in opposite hemispheres or separated

by the tentorium. They account for $0.15-8 \%$ of glial tumors. They must not show continuity with different lesions (microscopically or macroscopically), and should not be satellite lesions of a primary tumor [2]. Multifocal glioma consists of tumours separated by white matter tracts within the same hemisphere. Multifocal gliomas grow through commissural pathways, CSF channels, or the blood or by local extension through satellite formation [3]. Still there is no unified theory regarding the pathogenesis of multifocal and multicentric glioma, several hypotheses have been developed [4]. The traditionally held view of the pathogenesis of multifocal/multicentric glioma is by three possible pathways.

A. First, a previously known primary high-grade glioma spreads through the cerebrospinal fluid or white matter tracts to other locations.

B. Second, multiple areas of high-grade glioma arise de novo from initially non-neoplastic cells that are influenced by genetic defect.

C. Third and last, initially diffuse low-grade glioma develops separate from separate areas of malignant transformation within itself, hence giving rise to multifocal/ multicentric GBM.

Some literature proposes that the pathogenesis of multiple and multicentric glioma may involve neural stem cells within the sub ventricular zone (SVZ) or could result from tumor dissemination along white matter tracts and CSF pathways. Neural stem cells have been found to express matrix metalloproteinases, which are proteolytic enzymes implicated in tumor spread. Furthermore, the SVZ is thought to be a highly permissive environment for tumor growth and cellular migration [5]

Currently there is no clear guideline regarding the optimal management of multifocal or multicentric glioma. The treatment of multiple gliomas includes surgery, radiotherapy and chemotherapy. Aggressive resection of one tumor focus, biopsy alone followed by chemotherapy and radiation treatment, and multiple craniotomies during a single operation have all been described with no clear indication of which modality is superior. The prognosis of multiple gliomas remains unfavourable.

\section{References}

1. Li Z, Tian Y, Hu G, Xin Yu (2007) Multiple gliomas. J Clin Oncol 4(6): 379-383.

2. Andrea Arcos B, Lorena Romero B, Ramón Serramito A, Santína JM, Antonio Prieto A, et al. (02012) Miguel Gelabert a, Multicentric glioblastoma multiforme. Report of 3 cases, clinical and pathological study and literature review. neuroc i rugia 23(5): 211-215.

3. Zamponi N, Rychlicki F, Ducati A, Regnicolo L, Salvolini U, et al. (2001) Multicentric glioma with unusual clinical presentation. Childs Nerv Syst 17(1-2): 101-105.

4. Shakur SF, Bit-Ivan E, Watkin WG, Merrell RT, Farhat HI, et al. (2013) Multifocal and Multicentric Glioblastoma with Leptomeningeal Gliomatosis: A Case Report and Review of the Literature: Case Reports in Medicine, Article ID:132679, p. 8.

5. Yusuf ZC, Gürkanlar D, Erdener T (2005) Multicentric Gliomas: Still Remains a Controversial Issue. Turkish Neurosurgery 15(2): 71-75.

Your next submission with Juniper Publishers
will reach you the below assets
- Quality Editorial service
- Swift Peer Review
- Reprints availability
- E-prints Service
- Manuscript Podcast for convenient understanding
- Global attainment for your research
- Manuscript accessibility in different formats
( Pdf, E-pub, Full Text, Audio)
- Unceasing customer service
Track the below URL for one-step submission
https://juniperpublishers.com/online-submission.php

